\section{Enhanced Seed Germination of Ilex dumosa R. (Aquifoliaceae) through In Vitro Culture of Cut Pyrenes}

\author{
Natalia R. Dolce ${ }^{1}$, Luis A. Mroginski, and Hebe Y. Rey \\ Instituto de Botánica del Nordeste (IBONE), CONICET-UNNE, Facultad de \\ Ciencias Agrarias (UNNE), C.C. 209, (3400) Corrientes, Argentina
}

Additional index words. embryo rescue, seed dormancy, light, cold storage, holly

\begin{abstract}
An in vitro culture protocol was developed that increased the germination percentage and decreased the lag time to germination for Ilex dumosa R. pyrenes as a tool for replacing the laborious task of embryo rescue technique. This method involves transversely cutting surface-sterilized pyrenes with a scalpel blade, then placing the micropylar one-third end with the rudimentary embryo $(\approx 0.25 \mathrm{~mm}$ long) on solidified (agar $0.65 \%)$ quarter-strength salts and vitamins of Murashige and Skoog, 1962 medium with 3\% sucrose, and incubating in a growth room at $27 \pm 2{ }^{\circ} \mathrm{C}$ with a 14-h photoperiod (116 $\mu \mathrm{mol} \cdot \mathrm{m}^{-2} \cdot \mathrm{s}^{-1}$ ). Most of the cut pyrenes (greater than $50 \%$ ) germinated within the first month after inoculation and achieved maximum germination $(\approx 70 \%)$ in 2 months compared with whole pyrenes, which began to germinate 3 months after sowing and required more than 8 months for maximum germination (37\%). Moreover, the germination percentage of cut pyrenes was significantly higher than the germination of isolated embryos (34\%). Thus, the cut pyrenes culture is a simpler and more effective technique than embryo rescue. Easily, on average, a trained operator is able to culture $\approx 1000$ cut pyrenes per day instead of $\approx 100$ isolated embryos.
\end{abstract}

The genus Ilex L. (Aquifoliaceae) is the largest genus of woody dioecious plants with at least 600 species (Galle, 1997; Loizeau and Spichiger, 2004). They are generally deciduous and evergreen trees or shrubs occurring in temperate and tropical regions (Giberti, 1995; $\mathrm{Hu}, 1989)$. Various plant species are economically important. The English holly (I. aquifolium), the American holly (I. opaca), and the Chinese holly (I. cornuta) are cultivated for landscape architecture (Hu, 1989). The maté tree (I. paraguariensis) is a perennial crop whose leaves are used in Argentina, southern Brazil, Paraguay, and Uruguay for making a very popular stimulatory beverage, which has several health benefits (Schinella et al., 2005). Additionally, other species such as I. guayusa, I. tarapotina, and I. vomitoria are used in infusions (Loizeau, 1994). Lately, I. dumosa has awakened an interest from plant breeders as a result of the quality of its leaves for making "maté" with less caffeine that from I. paraguariensis (Filip et al., 1999, 2001) and the resistance of the plants to the main pests of the maté tree (Prat Kricun and Belingheri, 1995).

The dispersal unit of Ilex species is the pyrene, formed by the seed enclosed in a

Received for publication 12 May 2010. Accepted for publication 11 Aug. 2010.

We thank Luis Belingheri, E.E.A.-INTA Cerro Azul, Misiones, for providing the plant material. Special thanks are extended to CONICET, ANPCyT, and SGCyT (UNNE) for the financial support. This paper is part of the Ph.D. dissertation of the main author.

${ }^{1}$ To whom reprint requests should be addressed; e-mail ndolce@agr.unne.edu.ar. is necessary. In this study, we describe a reliable and reproducible method to propagate $I$. dumosa through in vitro culture of cut pyrenes.

\section{Materials and Methods}

Plant material. Open-pollinated ripe drupes of I. dumosa (Fig. 1A) were collected in February 2008 from trees at the EEA INTA Cerro Azul (Misiones, Argentina). The fruits were separated into three lots: 1) used immediately or 2) stored in a refrigerator at $4{ }^{\circ} \mathrm{C}$ for $30 \mathrm{~d}$ or 3 ) for $60 \mathrm{~d}$. Pyrenes from each lot were separated from the pulp and used immediately after isolation (Fig. 1B-C).

The plant material was prepared in a laminar flow hood. Pyrenes were surface-sterilized by soaking them in $70 \%$ ethanol for 2 min followed by immersion in an aqueous solution of $2.5 \%$ sodium hypochlorite and $0.1 \%$ Triton $\mathrm{X}-100^{\circledR}$ (Merck, Darmstadt, Germany) for $60 \mathrm{~min}$ and then rinsed three times in sterile distilled water. The sterilized pyrenes were separated into three lots: 1) used immediately or 2) stored in a refrigerator at $4{ }^{\circ} \mathrm{C}$ for $30 \mathrm{~d}$ or 3 ) for $60 \mathrm{~d}$.

In vitro germination of whole and cut pyrenes or isolated embryos from fresh fruits. Fruits immediately after their collection were used as the source of explants in this experiment. Three kinds of explants were inoculated: 1) whole pyrenes (Fig. 1C); 2) cut pyrenes (Fig. 1D) that were prepared under a stereomicroscope by transversely cutting the pyrenes with a scalpel blade and then culturing the micropylar one-third end with the rudimentary embryo; and $3)$ isolated embryos at the heart stage $(\approx 0.25$ $\mathrm{mm}$ long) that were separated from the endosperm following the procedure described by Mroginski et al. (2010). The explants were in vitro-cultured on $4 \mathrm{~mL}$ of solidified $(0.65 \%$ Sigma agar A-1296) MS/4 [quarter-strength salts and vitamins of Murashige and Skoog (1962) medium with $3 \%$ sucrose] in $11-\mathrm{cm}^{3}$ glass tubes (six explants/tube). The $\mathrm{pH}$ of the medium was adjusted to 5.8 with $\mathrm{KOH}$ or $\mathrm{HCl}$ before adding agar. The tubes with media were sterilized by autoclaving at $1.45 \mathrm{~kg} \cdot \mathrm{cm}^{-2}$ and $120{ }^{\circ} \mathrm{C}$ for $20 \mathrm{~min}$. Cultures were sealed with Resinite AF $50^{\circledR}$ (Casco S.A.I.C. Company, Bs.As., Argentina) and incubated in a growth room at $27 \pm 2{ }^{\circ} \mathrm{C}$ with a 14 -h photoperiod (116 $\left.\mu \mathrm{mol} \cdot \mathrm{m}^{-2} \cdot \mathrm{s}^{-1}\right)$.

In vitro germination of whole and cut pyrenes from cold stored fruits and pyrenes. Fruits and surface-sterilized pyrenes stored at $4{ }^{\circ} \mathrm{C}$ for 30 or $60 \mathrm{~d}$ were used as the source of explants in this experiment. Moreover, pyrenes from fresh fruits were used as a control treatment. In all cases, whole and cut pyrenes were in vitro-cultured on MS/4 as described previously and incubated in a growth room at $27 \pm 2{ }^{\circ} \mathrm{C}$ with a 14 -h photoperiod or in darkness.

Germination of whole or cut pyrenes on different substrates under aseptic or nonaseptic conditions. Whole or cut pyrenes were sowed under aseptic conditions in germinators consisting of $90 \times 15-\mathrm{mm}$ glass petri dishes ( 30 explants/dish) containing $40 \mathrm{~mL}$ of solidified $\mathrm{MS} / 4$ or with a 5-mm layer of cotton and filter paper or Sphagnum peat soaked with sterile 
distilled water. Pyrenes were surface-sterilized and petri dishes were sterilized as described previously. Additionally, whole or cut pyrenes were sowed under non-aseptic conditions in petri dishes containing $40 \mathrm{~cm}^{3}$ of sand or with a 5-mm layer of cotton and filter paper or Sphagnum peat soaked with distilled water. In all cases, germinators with whole or cut pyrenes were sealed with Resinite AF $50^{\circledR}$ and incubated in a growth room at $27 \pm 2{ }^{\circ} \mathrm{C}$ with a 14-h photoperiod.

All treatments were assayed every $30 \mathrm{~d}$ for germination percentages until $300 \mathrm{~d}$ after inoculation. When isolated embryos were cultured, the gradual change in shape of the immature embryos was observed until germination. This change was characterized by radicle elongation followed by immediate hypocotyl elongation and cotyledon expansion. When whole and bisected pyrenes were cultured, the emergence of the shoot and/or root was used as the criterion to calculate germination rate (Fig. 1E-F).

Statistical analysis. The treatments were arranged in a completely randomized design with three replicates of 30 or 60 samples per treatment. The data were subjected to analysis of variance (ANOVA) and the significance of mean differences was determined using Tukey's multiple comparison test $(P<0.05)$.

Percentage data were transformed using the square root for the cold storage experiment and the transformation $\log (2+\%$ germination $)$ for the different substrates experiment. The normality of the transformations was verified before applying the ANOVA by the ShapiroWilks test $(P<0.05)$.

\section{Results and Discussion}

After $30 \mathrm{~d}$ inoculation, the results of in vitro culture of whole and cut pyrenes or isolated embryos from fresh fruits (Fig. 2) showed that although the germination of whole pyrenes was nil, as much as $51 \%$ of the cut pyrenes germinated. This percentage was significantly higher than that of isolated embryos (34.4\%), which is similar to the one obtained previously (Sansberro et al., 2001). After $60 \mathrm{~d}$ of culture, this difference increased, achieving germination percentages of $67.2 \%$ and $34.4 \%$ from cut pyrenes and isolated embryos, respectively. Thus, the in vitro culture of cut pyrenes, besides being a simpler technique, is more efficient than the culture of isolated embryos to obtain quick germination of I. dumosa embryos.

It is interesting to note that the rest of its own endosperm (cut pyrenes) improved the germination of I. dumosa embryos compared with inoculation of isolated embryos (Fig. 2). This result is in disagreement with that reported by $\mathrm{Hu}$ et al. (1979) who have reported that the growth of isolated embryos of $I$. aquifolium, I. cornuta, and I. opaca in vitro was drastically reduced when the embryos were cultured adjacent to their own endosperm and they have strongly suggested the presence of growth inhibitors in Ilex endosperm and/or in the membrane-like testa attached to the endosperm. However, no attempt
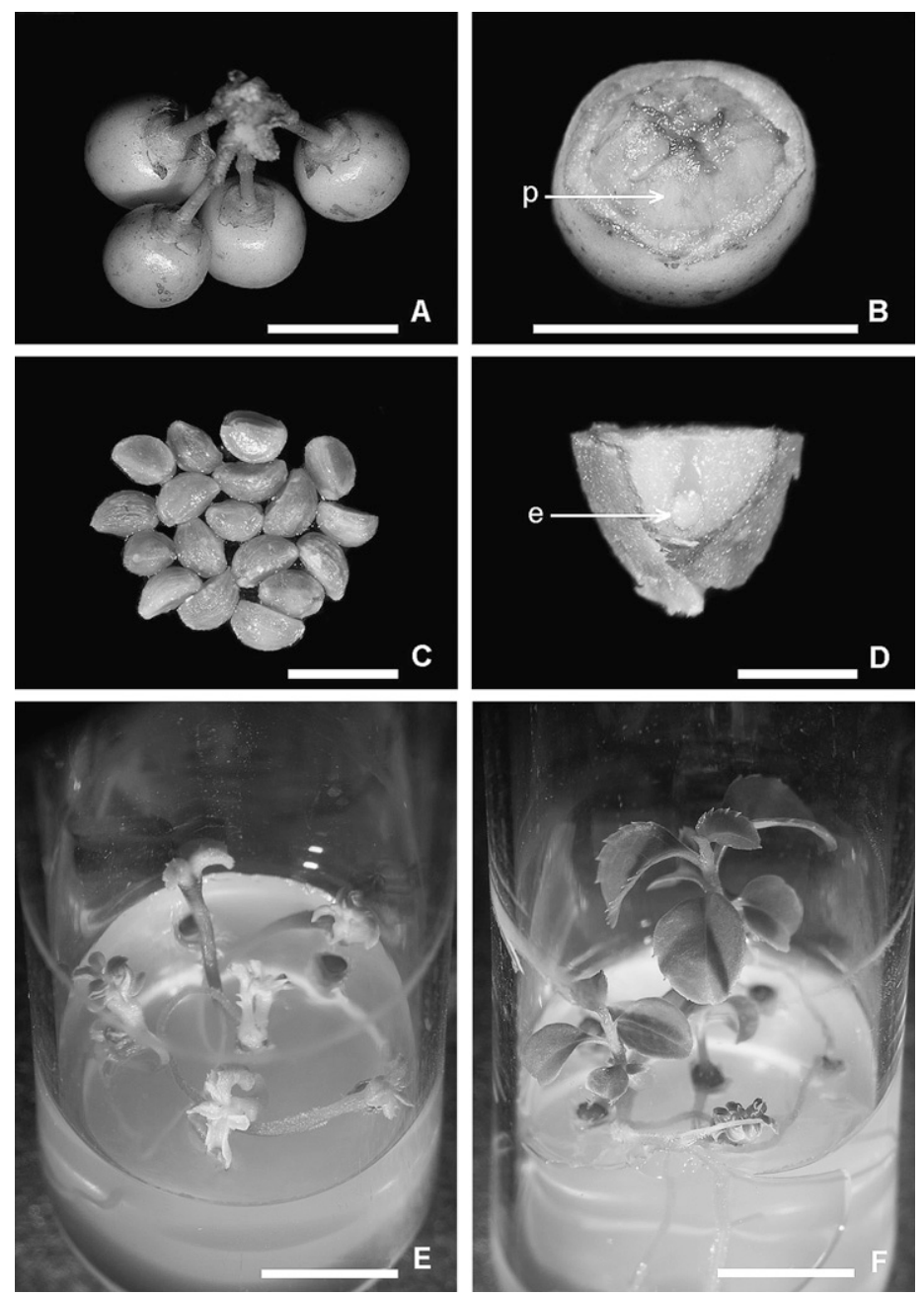

Fig. 1. Ilex dumosa (A) fruits. (B) Fruit showing four pyrenes. Arrows shows a pyrene. (C) Pyrenes. (D) Cut pyrene showing the embryo. (E-F) Cut pyrenes germinated after (E) $30 \mathrm{~d}$ and (F) $60 \mathrm{~d}$ cultured on $\mathrm{MS} / 4$ and incubated in a growth room at $27 \pm 2{ }^{\circ} \mathrm{C}$ with a $14-\mathrm{h}$ photoperiod. Bars represent $5 \mathrm{~mm}$ in $\mathbf{A}$, $\mathbf{B}, \mathbf{C}, \mathbf{E}, \mathbf{F}$; in $\mathbf{D}$ represent $1 \mathrm{~mm}$.

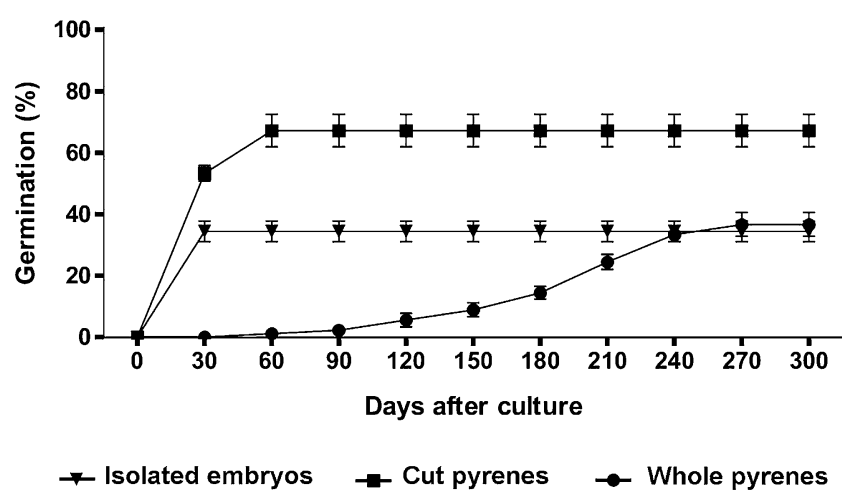

Fig. 2. Germination time courses of isolated embryos, whole and cut Ilex dumosa pyrenes cultured on MS/4 and incubated in a growth room at $27 \pm 2{ }^{\circ} \mathrm{C}$ with a 14 -h photoperiod. Bars indicate SE.

has been made to isolate and identify these putative inhibitors.

On the other hand, germination of whole pyrenes was not observed until after at least 3 months and it still took 9 months to achieve maximum germination $(37.8 \%)$. Therefore, cutting pyrenes increased germination and decreased the time to maximum germination compared with whole pyrenes. Similar results have been reported by Miller et al. (1992) and Ke et al. (1985) for Fragaria achenes and Rubus seeds, respectively. Thus, this technique may be applicable to many crop seeds that have a hard coat surrounding the embryo.

It is not very well known how cutting affects pyrenes, achenes, and other seeds with 
Table 1. Germination (\%) of Ilex dumosa pyrenes with or without a cold treatment $\left(4{ }^{\circ} \mathrm{C}\right)$ after $30 \mathrm{~d}$ cultured on MS/4 and incubated in a growth room at $27 \pm 2{ }^{\circ} \mathrm{C}$ with a 14 -h photoperiod or in darkness. ${ }^{\mathrm{z}}$

\begin{tabular}{|c|c|c|c|c|}
\hline \multirow[b]{3}{*}{ Treatment } & \multicolumn{4}{|c|}{ Culture condition } \\
\hline & \multicolumn{2}{|c|}{ Light } & \multicolumn{2}{|c|}{ Darkness } \\
\hline & Whole pyrenes & $\overline{\text { Cut pyrenes }}$ & Whole pyrenes & Cut pyrenes \\
\hline Fresh fruits, AT & 0.0 & $56.7 \mathrm{a}$ & 0.0 & $27.8 \mathrm{a}$ \\
\hline Fruits, $30 \mathrm{~d} 4{ }^{\circ} \mathrm{C}$ & 0.0 & $47.8 \mathrm{ab}$ & 0.0 & $16.7 \mathrm{a}$ \\
\hline Fruits, $60 \mathrm{~d} 4{ }^{\circ} \mathrm{C}$ & 0.0 & $23.3 \mathrm{c}$ & 0.0 & $10.0 \mathrm{a}$ \\
\hline Pyrenes, $30 \mathrm{~d} 4{ }^{\circ} \mathrm{C}$ & 0.0 & $50.0 \mathrm{ab}$ & 0.0 & $18.9 \mathrm{a}$ \\
\hline Pyrenes, $60 \mathrm{~d} 4{ }^{\circ} \mathrm{C}$ & 0.0 & $31.1 \mathrm{bc}$ & 0.0 & $12.2 \mathrm{a}$ \\
\hline
\end{tabular}

${ }^{\mathrm{z}}$ Within the columns means followed by different letters are significantly different (Tukey's multiple comparison test; $P<0.05$ ).

$\mathrm{AT}=$ ambient temperature.

Table 2. Effect of different substrates on germination percentage of Ilex dumosa pyrenes after $30 \mathrm{~d}$ sowed and incubated in a growth room at $27 \pm$ $2{ }^{\circ} \mathrm{C}$ with a $14-\mathrm{h}$ photoperiod. ${ }^{\mathrm{z}}$

\begin{tabular}{llcc}
\hline & & \multicolumn{2}{c}{ Germination (\%) } \\
\cline { 3 - 4 } Culture condition & & $\begin{array}{c}\text { Whole } \\
\text { pyrenes }\end{array}$ & $\begin{array}{c}\text { Cut } \\
\text { pyrenes }\end{array}$ \\
\hline Aseptic & MS/4 & 0.0 & $52.2 \mathrm{a}$ \\
& Paper & 0.0 & $14.4 \mathrm{ab}$ \\
\multirow{5}{*}{ Non-aseptic } & Sphagnum & 0.0 & $5.6 \mathrm{bc}$ \\
& Sand & 0.0 & $2.2 \mathrm{c}$ \\
& Paper & 0.0 & $3.3 \mathrm{bc}$ \\
& Sphagnum & 0.0 & $2.2 \mathrm{c}$ \\
\hline
\end{tabular}

${ }^{\mathrm{z}}$ Within the columns means followed by different letters are significantly different (Tukey's multiple comparison test; $P<0.05$ ).

hard coats and promotes faster and higher germination percentages than for control seeds. Possible explanations for the cut seed effect are: 1) cutting may mimic mechanical scarification, which makes the tissue surrounding the embryo permeable to water and gases (Hartmann and Kester, 1959); 2) the hard endocarp acts as a physical barrier to the expansion and germination of the embryo and cutting seems to be an effective means to break the barrier; and 3) the endosperm may contain one or more endogenous germination inhibitors. After cutting the seeds, the inhibitor(s) may diffuse away from the embryo and germination might occur (Miller et al., 1992).

The cold storage $\left(4^{\circ} \mathrm{C}\right)$ of either fruits or isolated pyrenes did not improve the germination percentage of $I$. dumosa pyrenes (Table 1). Although cut pyrenes from fruits and whole pyrenes stored for $30 \mathrm{~d}$ at $4{ }^{\circ} \mathrm{C}$ exhibited similar germination percentages as the cut unstored control pyrenes, the cold storage for a longer period (60 d) decreased germination compared with the control treatment when cut pyrenes were incubated in light. These results are not in agreement with Dolce et al. (2010) and Sansberro et al. (2000) who have found that low-temperature treatment increased the germination percentage of I. paraguariensis isolated embryos and cut pyrenes cultured in vitro. In many species, exposition of seeds to low temperatures decreases the endogenous content of abscisic acid and increases the gibberellin and cytokinin levels, which interact in a sequential way to break dormancy (Bewley and Black, 1994). On the other hand, the light regime had a significant effect on germination of I. dumosa cut pyrenes (Table 1) and subsequent seedling growth. Incubation in continuous dark resulted in significantly lower germination and severe inhibition of the seedling growth. Cultures maintained in darkness were etiolated with cotyledonary leaves scarcely developed and lacked true leaves. Instead, seedlings germinated under a 14 -h photoperiod were green and vigorous with four true leaves in most of cases after 2 months of cutting and sowing the pyrenes. This response differs from that reported by Ferreira and $\mathrm{Hu}(1989)$ and $\mathrm{Hu}$ (1976) for isolated embryos of I. opaca, I. aquifolium, and I. paraguariensis, whose in vitro late embryogeny was light-inhibited.

The substrate had a relevant effect on $I$. dumosa seed germination (Table 2). Although cut pyrenes germinated after $30 \mathrm{~d}$ culture in all of the substrates assayed, the germination percentage was significantly higher when they were inoculated in aseptic conditions on solidified MS/4. Moreover, when cut pyrenes were cultured under non-aseptic conditions, the germination was nearly void. On the other hand, the germination of whole pyrenes was nil in all the conditions assayed after $30 \mathrm{~d}$ culture. Although 8 months after sowing, they germinated, the percentages were very poor (between $1 \%$ and $5 \%$ ) when whole pyrenes were cultured under non-aseptic conditions. For comparison, when whole pyrenes were sowed under aseptic conditions, they achieved higher germination percentages $(36 \%, 23 \%$, and $12 \%$ from pyrenes placed on $\mathrm{MS} / 4$, papercotton, and Sphagnum peat, respectively) after 8 months of culture. The cause of the poor germination for pyrenes inoculated under nonaseptic conditions may be largely pathogen responsibility. During the extended time required for the embryo maturation, the seeds are prone to suffering attack by pathogens and heavy pre-germination mortality.

In conclusion, these studies demonstrate for the first time that the in vitro germination of I. dumosa cut pyrenes may be achieved readily and may be an alternative to embryo rescue. The culture of cut pyrenes is a simpler and more effective technique than the culture of isolated embryos. Easily, on average, a trained operator is able to culture $\approx 1000$ cut pyrenes per day instead of $\approx 100$ isolated embryos.

\section{Literature Cited}

Bewley, J.D. and M. Black. 1994. Seeds: Physiology of development and germination. 2nd Ed. Plenum Press, New York, NY.
Dolce, N.R., L.A. Mroginski, and H.Y. Rey. 2010. Endosperm and endocarp effects on the Ilex paraguariensis A. St.-Hil. (Aquifoliaceae) seed germination. Seed Sci. Technol. 38:441-448.

Fay, M.F. 1992. Conservation of rare and endangered plants using in vitro methods. In Vitro Cell. Dev. Biol. Plant 28:1-4.

Ferreira, A.G., G.G. Cunha, T.S. da Silva, and C.Y. Hu. 1991. In vitro germination of immature embryos of Ilex paraguariensis St. Hil. Phyton 52:27-32.

Ferreira, A.G. and C.Y. Hu. 1989. Light-mediated inhibition of in vitro late embryogeny of Ilex. J. Amer. Soc. Hort. Sci. 114:819-823.

Filip, R., P. López, G.C. Giberti, J. Coussio, and G. Ferraro. 2001. Phenolic compounds in seven South American Ilex species. Fitoterapia 72: 774-778.

Filip, R., P.J. López, and G.E. Ferraro. 1999. Phytochemical study of Ilex dumosa. Acta Hort. 501:333-336.

Galle, F.C. 1997. Hollies: The genus Ilex. Timber Press, Portland, OR.

Giberti, G.C. 1995. Florística, sistemática y potencialidades con relación a un banco de germoplasma para la yerba mate, p. 303-312. In: Winge, H., A. Ferreira, J. Mariath and L. Tarasconi (eds.). Erva-Mate: Biologia e Cultura no Cono Sul. Univ. Federal do Rio Grande do Sul, Brasil.

Hartmann, H.T. and D.E. Kester. 1959. Plant propagation: Principles and practices. PrenticeHall, Englewood Cliffs, NJ.

$\mathrm{Hu}, \mathrm{C.Y} .1975$. In vitro culture of rudimentary embryos of eleven Ilex species. J. Amer. Soc. Hort. Sci. 100:221-225.

Hu, C.Y. 1976. Light-mediated inhibition of in vitro development of rudimentary embryos of Ilex opaca. Amer. J. Bot. 63:651-656.

Hu, C.Y. 1989. Holly (Ilex spp.), p. 412-427. In: Bajaj, Y.P.S. (ed.). Biotechnology in agriculture and forestry. Vol. 5. Springer-Verlag, Berlin, Germany.

Hu, C.Y., F. Rogalski, and C. Ward. 1979. Factors maintaining Ilex rudimentary embryos in the quiescent state and the ultrastructural changes during in vitro activation. Bot. Gaz. 140:272-279.

Ives, S.A. 1923. Maturation and germination of seeds of Ilex opaca. Bot. Gaz. 76:60-77.

Ke, S., R.M. Skirvin, K.D. McPheeters, A.G. Otterbacher, and G. Galleta. 1985. In vitro germination and growth of Rubus seeds and embryos. HortScience 20:1047-1049.

Loizeau, P.A. 1994. Les Aquifoliaceas péruvinnes. Boissiera 48:1-306.

Loizeau, P.A. and R. Spichiger. 2004Aquifoliaceae, p. 26-28. In: Smith, N., S. Mori, A. Henderson, D. Stevenson, and S. Heald (eds.). Flowering plants of the Neotropics. Princeton University Press, Princeton, NJ.

Miller, A.R., J.C. Scheerens, and P.S. Erb. 1992. Enhanced strawberry seed germination through in vitro culture of cut achenes. J. Amer. Soc. Hort. Sci. 117:313-316.

Mroginski, L., N. Dolce, P. Sansberro, C. Luna, A. Gonzalez, and H. Rey. 2010. Techniques and protocol on the cryopreservation of Ilex immature zygotic embryo. In: Thorpe, $\mathrm{T}$. and $\mathrm{C}$. Yeung (eds.). Plant embryo culture: Methods and protocols. Humana Press, New York, NY (In press).

Murashige, T. and F. Skoog. 1962. A revised medium for rapid growth and bioassays with tobacco tissue cultures. Physiol. Plant. 15: 473-497.

Niklas, C.O. 1987. Estudios embriológicos y citológicos en la yerba mate Ilex paraguariensis (Aquifoliaceae). Bonplandia 6:45-56. 
Prat Kricun, S.D. and L.D. Belingheri. 1995. Recolección de especies silvestres y cultivadas del género Ilex, p. 313-321. In: Winge, H., A. Ferreira, J. Mariath, and L. Tarasconi (eds.) Erva-Mate: Biologia e Cultura no Cone Sul. Univ. Federal do Rio Grande do Sul, Brasil.

Sansberro, P.A., H.Y. Rey, and L.A. Mroginski. 2000. Efectos de bajas temperaturas en la germinación in vitro de embriones inmaduros de yerba mate, p. 443-446. In: Winge, H. (ed.).
Annals II Congresso Sul-Americano da ErvaMate e III Reunião Técnica da Erva-Mate. Univ. Federal do Rio Grande do Sul and Fundação Estadual de Pesquisa Agropecuária, Brasil.

Sansberro, P.A., H.Y. Rey, and L.A. Mroginski. 2001. In vitro culture of zygotic embryos of Ilex species. HortScience 36:351-352.

Sansberro, P.A., H.Y. Rey, L.A. Mroginski, and M.M. Collavino. 1998. In vitro culture of rudimentary embryos of Ilex paraguariensis:
Responses to exogenous cytokinins. J. Plant Growth Regul. 17:101-105.

Sharma, D.R., R. Kaur, and K. Kumar. 1996. Embryo rescue in plants - A review. Euphytica 89:325-337.

Schinella, G., J.C. Fantinelli, and S.M. Mosca. 2005. Cardioprotective effect of Ilex paraguariensis extract: Evidence for a nitric oxidedependent mechanism. Clin. Nutr. 24:360 366. 